\title{
Lost without you: the Value of Falling out of Love
}

\section{Pilar Lopez-Cantero ${ }^{2} \cdot$ Alfred Archer $^{1}$}

Accepted: 5 February 2020/Published online: 18 February 2020

(C) The Author(s) 2020

\begin{abstract}
In this paper we develop a view about the disorientation attached to the process of falling out of love and explain its prudential and moral value. We start with a brief background on theories of love and situate our argument within the views concerned with the lovers' identities. Namely, love changes who we are. In the context of our paper, we explain this common tenet in the philosophy of love as a change in the lovers' self-concepts through a process of mutual shaping. This, however, is potentially dangerous for people involved in what we call 'subsuming relationships', who give up too much autonomy in the process of mutual shaping. We then move on to show how, through the relation between love and the self-concept, we can explain why the process of falling out of love with someone is so disorientating: when one is falling out of love, one loses an important point of reference for self-understanding. While this disorientating process is typically taken to be harmful to the person experiencing it, we will explain how it can also have moral and prudential value. By re-evaluating who we were in the relationship and who we are now, we can escape from oppressive practices in subsuming relationships. We finish by arguing that this gives us reason to be wary of seeking to re-orient ourselves -or others- too quickly after falling out of love.
\end{abstract}

Keywords Philosophy of love - Disorientation - Ethics of love · Ethics · Philosophy of emotion · Feminist philosophy

Alfred Archer

a.t.m.archer@uvt.nl

Pilar Lopez-Cantero

p.lopezcantero@tudelft.nl

1 Department of Philosophy, Tilburg School of Humanities, Warandelaan 2, 5037 AB Tilburg, The Netherlands

2 Department of Philosophy, Delft University of Technology, Jaffalaan 5, Delft 2628 BX, The Netherlands 


\section{Introduction}

Falling out of love is a delicate and important business, and as necessary to the attainment of wisdom as the reverse experience.

Stella Bowen (2002: 82).

After being in a romantic partnership with someone, falling out of love with someone can be a painful experience. Sometimes, we fall out of love with a person that still loves us. The thought of hurting them may cause us emotional pain and feelings of guilt. At other times, we realise that we need to fall out of love with someone we still care about. This may also be a painful process filled with denial, anger and self-pity.

Besides causing emotional pain, falling out of love with someone one is -or was - in a loving relationship with can be potentially disruptive for self-understanding. As a situating example, think about the following statement, made after losing her two lovers by Rebecca Bloom, of the TV show Crazy Ex-Girlfriend: "I don't know who I am without them. I know that's pathetic. I know it's pathetic, but it's true. Who am I supposed to be now?" Rebecca's statement reflects a feature of the end of relationships which has been documented in psychological studies as a decrease in 'self-concept clarity'. By this is meant a decrease in "the extent to which the contents of an individual's self-concept (e.g., perceived personal attributes) are clearly and confidently defined, internally consistent, and temporally stable" (Campbell et al. 1996: 141). It has been found that exiting a relationship has a special negative effect on self-concept clarity: "expartners must renegotiate their sense of self without the facets defined by the relationship, leaving their self-concepts less clearly defined (at least temporarily)" (Slotter et al. 2010: 148-149). Rebecca's quote is more than a series of melodramatic statements: it reflects a loss of clarity which often accompanies the end of romantic partnerships and, as we will argue, the end of love.

In that sense, the process of falling out of love is intimately connected with what Ami Harbin (2016: 2) calls disorientations: "temporally extended major life experiences that make it difficult for individuals to know how to go on". It may seem that "not knowing how to go on' is an undesirable state by itself. Here we show that, quite to the contrary, the disorientation attached to the process of falling out of love can have moral and prudential value. This is the case especially in cases of what we call subsuming relationships, relationships involving a subordination of one's autonomy often rooted in power imbalance.

We start by giving a brief background on theories of love, and show how several differing views share the idea of love entailing a change in the lovers' identities. We situate this change at the level of the self-concept, and show the dangers of giving up too much autonomy in romantic partnerships, characterised by a process of mutual shaping of the self-concept. We then explain the process of falling out of love as one of profound disorientation and explain why this process may have both moral and prudential value: by re-evaluating who we were in the relationship and who we are now, we can escape from oppressive practices which are sometimes linked to romantic partnerships. We finish by arguing that this gives us reason to be wary of seeking to re-orient ourselves -or others- too quickly after falling out of love. 


\section{Defining Love Through Identity}

The process of falling out of love may happen before or after exiting a relationship, and in either case it entails the end of love. Falling out of love does not, as we mention above, necessarily mean that one 'falls out of caring' for the beloved. ${ }^{1}$ In order to properly situate how we understand what falling out of love is, we must start by delimiting our working definition of love; and specifically of romantic love.

Analytical accounts of love have followed four typical routes of conceptual analysis. The love as an emotion accounts analyse the metaphysical status of love as an emotional phenomenon, with a general consensus that love is not merely a bodily feeling, but some kind of emotional complex (Abramson and Leite 2011; Naar 2013). The love as valuing accounts see love as a kind of valuing another, and are generally focused on the justifying reasons for love (Keller 2000; Kolodny 2003). The robust concern accounts see love as a specific way of caring for another which may be beyond rational justification (Soble 1990; Frankfurt 2004). Finally, the union accounts define love as a sort of merging of the lovers' identities in different degrees (Nozick 1989; Friedman 1998, 2003). Some accounts of love do not follow one of these routes exclusively, and some other accounts follow none. With this, we merely show that there is a multiplicity of routes to explain what love is, and any conceptual analysis related to love requires a choice between these.

Here, we focus on an aspect of love in which both union theorists and robust concern theorists agree, and which is not prima facie controversial for theorists following other routes: the fact that love frequently entails a change in the lovers. This link between love and change in the lovers has been part of the Western philosophical discussion of love at least since Plato's Symposium. In contemporary philosophy, it has been expressed in terms of joint identity (in union accounts) or identification with another (in robust concern accounts).

Robert Nozick (1989) and Marilyn Friedman (1998) are two of the leading proponents of love as the creation of a joint identity. Nozick defines love as the desire to form a we, a joint identity which is constituted by a pooling of autonomy, well-being, and desires by the members of the relationship (1989: 418). Marilyn Friedman develops this idea further and says that loves entails the creation of a shared identity akin to a 'federation of states'. In such a federation, two states join together for certain joint ventures, whilst maintaining some individual powers (Friedman 1998: 108).

In robust concern accounts, love is not so much analysed in terms of shared or joint identity, but a specific way of caring for the beloved partly grounded on what Harry Frankfurt (2004: 62) calls 'identification': the incorporation of the interests of the beloved, which become "analogous" to the interests of the lover. Ultimately, love constrains the lovers' wills, who become re-orientated to mutual well-being.

Bennet Helm (2010) criticises both approaches. According to Helm, union and robust concern accounts offer an egotistical conception of love, given that the lover only cares about the beloved's interests because they are the lover's interests now - let it be because she now participates of a joint identity, or because the beloved's interests become analogous to her

\footnotetext{
${ }^{1}$ We are grateful to an anonymous referee for providing us with this expression. As it was pointed out to us, when falling out of love, someone may continue to care deeply about their former beloved, to the point of desiring to still be in love with their former beloved. It may even be that the fact this care motivates attempts to 'rekindle the fire', i.e. to fall in love again with that person.
} 
interests (Helm 2010: 18). Instead, Helm argues that loving someone is to care about her interests, without the need to incorporate these into one's own. Specifically, to love is to be rationally committed to a pattern of concern towards certain values of the beloved: the features of a life that person considers worth living (2010: 42). ${ }^{2}$ Given that this pattern of concern is mutual, the lover and the beloved end sharing a single evaluative perspective (2010: 34 ). Thus, Helm develops an account which aims to achieve the best of both worlds in terms of joint identity and identification.

Whether Helm succeeds or not, and whether he is right in his criticism of union and robust concern accounts, goes beyond of the scope of this paper. What we want to show is that it is a commonly accepted idea across very different positions in the philosophy of love that love changes the lovers' identities by changing their respective interests or priorities. The disagreements among these approaches lay on the degree that interests need to be shared (all or some of them); on the metaphysical implications of this sharing of interests (the creation of a new joint identity; the change of one's volitional structure; the acquisition of a single evaluative perspective); and on the ontological relation of this change with love (whether love is this change or entails this change). We are not interested in these disagreements, but in the element of change that all these authors agree that is at least an element of love.

We are specifically interested in the way loving someone changes what Helm calls 'values': things that, for a person, are integral components of the kind of life that person considers worth living. If love entails the acquisition of new values, let them be apparently insignificant -like football or upcycling- or more grandiose -like philosophy or political activism-, then this is an illuminating feature of love that all these authors agree on. It is in this sense that the authors in the described approaches understand interests implicitly or explicitly, and it is for that reason that they see love as a change in the lovers' identities.

This, however, opens a whole new field with a multiplicity of approaches, each of them with significant metaphysical baggage regarding the nature of personal identity, autonomy, shared agency, or all of those. It is not our intention to engage with those debates, so, instead, we take the claim a step down in a way that still captures the change in the lovers that is captured by the accounts above: love entails a change in the lovers' self-concepts, and thus contributes to shaping them. We understand self-concept in the traditional psychological sense, as an umbrella term which encompasses identity and selfhood, and which is defined as the beliefs a person has about who she is (Baumeister 2005). These beliefs need not be conscious: as we said earlier, a person can have a greater or lesser degree of self-concept clarity, that is, these beliefs may be more or less defined and clear. Situating our view at the level of the self-concept allows us to build from the idea of love entailing a change in the lovers without the need to endorse a specific view on selfhood or identity. Whatever the metaphysical status of 'who a person is', that person has certain beliefs about herself which she acts upon, and are informed by the ways in which she acts (Walker 2012: 65). This is what is important for our argument.

\footnotetext{
${ }^{2}$ Helm's values mirror what Christine Korsgaard (1996: 101) calls 'practical identities': “description[s] under which you value yourself and find your life worth living and your actions worth undertaking". Korsgaard's practical identities are bound with her Kantian conception of agency, which is incompatible with having practical identities that are morally questionable. Helm remains neutral in that respect (2010: 98). Since we are not making a moral claim here, we stick to Helm's 'values'.
} 


\section{How Love Shapes the Self-Concept}

Cocking and Kennett (1998) describe how love can shape the lovers' self-concept. According to Cocking and Kennet's 'drawing view', it is a condition for friendship that the friends are receptive to being mutually "directed and interpreted" (1998: 503). Here, we understand their view as applying to romantic love too. ${ }^{3}$

The first component of the drawing view is direction: to be directed by someone is for that person to contribute to shaping one's choices. It is not a matter of being told what to choose (what to think or what to do), but a matter of our thoughts and actions changing in virtue of the interests of the people we love. In friendship, Cocking and Kennett say, "each person is receptive to developing interests or activities, which they do not already pursue, primarily because they are the interests and activities of the other" (1998: 503504). By having one's choices directed by a friend, one's self-concept may change; for example, ballet may become part of one's own set of interests, even after the relationship is over.

On the basis of this receptivity to my friend's interests, aspects of my character may change in ways that they otherwise might not have and such changes may persist beyond the friendship. I might get infected by Iris's enthusiasm for ballet; typically, I will at least be interested in understanding and appreciating it, simply because she loves it. Thus I may change from someone who had a marked distaste for high culture to someone with a genuine appreciation of the athleticism and grace of dance. (Cocking and Kennett 1998: 504)

The change brought about in the lovers is even more patent through interpretation -the other component of the drawing view. When we are friends with someone, Cocking and Kennett point out, we recognise features of their actions and character and make observations about them. We do not need to be similar to someone to interpret their actions and character (Cocking and Kennett 1998: 509); as is clear from the fact that friends and lovers can be very different from each other. Having our behaviour interpreted by another can result in a change of our self-concept.

Cocking and Kennett capture the common idea of the views of love in the previous section: what lovers do together, and what lovers tell each other about what they think of each other, contributes to the mutual shaping of the lovers' self-concepts. This not only captures and explains the common idea, but it also reveals something that Helm (2010: 10-12) claims most accounts of love overlook: that our self-concepts are not created in isolation from others, and that people who we stand in personal relationships with have a privileged position to contribute to the shaping of our self-concept. ${ }^{4}$

\footnotetext{
${ }^{3}$ We follow Helm in thinking that, although there are differences between friendship and romantic love, these differences are best understood "in terms of the particular ways the parties involved conceive of and negotiate the details of the relationships" (Helm 2010: 4). In any case, even if romantic love and friendship were different in kind, the shaping of the self-concept is not what marks the difference, since this mutual shaping is common to both friendship and romantic love. For that reason, it is legitimate to ask whether the argument we make here applies to falling out of love only, and not the end of other relationships as well -like ending a friendship or severing family ties. We acknowledge that this is a possibility which could be explored in the context of our view, but our argument here is exclusively about falling out of love.

${ }^{4}$ A similar point is made in Angelika Krebs's (2014) dialogical view of love.
} 
The fact that lovers contribute to shape our self-concepts means that we have to relinquish a degree of autonomy over our own self-concepts. ${ }^{5}$ We understand autonomy in the same basic sense Helm does, as the capacity to determine one's values that make one life worth living. The fact that lovers contribute to shape these values (at least at the self-concept level) can sometimes result in imbalanced relationships. We consider a relationship is imbalanced if it requires that one member of the relationship gives up significantly more autonomy than the other. We might, for example, convince ourselves to watch opera when we would rather watch super-hero films, just because our beloved is interested in the opera. We might also come to believe that we are not very good at organising things because our beloved tells us so, when that is not really the case. We might even get to the point of replacing all of our interests and substituting them for the beloved's: go from watching super-hero movies, attending comic-cons and eating in fast food chains to spending weekends at the opera, and dining on posh canapés in European theatres. Or it might be that, although we do not replace all of our interests, we end up prioritising the others' interests too much. Imbalanced relationships can be damaging; here we call damaging imbalanced relationships subsuming relationships (since, as we explain later, not all imbalanced relationships are damaging). Subsuming relationships may not sound damaging when one gives up one's interests and acquires the beloved's interest in opera, but what if, for example, the beloved's interests are not the opera but risk-taking, gambling or taking drugs? And what if the mutual shaping is built upon a power imbalance between the members of the relationship? The danger of subsuming relationships, specifically with regard to power imbalances, has been at the centre of feminist critiques of romantic love.

Friedman makes precisely this point. According to Friedman, when the merging of identities (which we are understanding here as the mutual shaping of the self-concept) takes place between two people with very different levels of power this may threaten the interests and autonomy of the less powerful person in the relationship. Friedman (2003: 125) provides a long list of the various ways in which this could happen, some of which involve the replacement and/or prioritisation of interests which is inherent to the claim that love shapes the lover's identities/self-concepts. This replacement and/or prioritisation is damaging when one of the members of the relationship becomes fundamentally less autonomous with respect to their self-concept than the other.

It is possible for all different kinds of people to be on the wrong end of subsuming relationships. A man in a relationship with a woman or another man may find his autonomy subordinated in this way, as might a woman in love with another woman. However, Friedman (2003: 127) notes that women in romantic love affairs with men are particularly vulnerable to having their autonomy diminished in this way. Simone de Beauvoir (1949 [2011]) argued that women find themselves in a situation of immanence, where they are denied the possibility of being an independent, free and transcendent subject. Love, claims de Beauvoir, presents an

\footnotetext{
${ }^{5}$ Catriona Mackenzie and Jacqui Poltera (2010: 49-50) argue that one can be more or less autonomous from one's self-concept. People who suffer certain psychopathologies, for example, experience episodes where they are not autonomous from their self-concept. We intend what we say here to be compatible with a wide range of views about what autonomy consists of, including relational accounts of autonomy, according to which a person's identity or self-concept is in part constituted by social relationships. As Marina Oshana (2006) points out, such views are consistent with the idea that the social situation one finds oneself in may undermine one's autonomy by making it the case that someone lacks practical control over their life. Thanks to an anonymous referee for pressing us on this point.
} 
opportunity for women to transcend their situation by joining with a sovereign male subject. As she explains (1949 [2011]: 700):

Closed off in the sphere of the relative, destined for the male from her earliest childhood, used to seeing him as a sovereign, with whom equality is not permitted, the woman who has not suppressed her claim to be human will dream of surpassing her being towards one of those superior beings, of becoming one, of fusing with the sovereign subject.

However, de Beauvoir argues that this desire to fuse with the beloved in order to achieve transcendence is an act of bad faith, as rather than achieving freedom the woman who acts in this way instead embraces her subordinate position. In de Beauvoir's words (1949 [2011]: 700):

[S]he chooses to want her enslavement so ardently that it will seem to her to be the expression of her freedom; she will try to overcome her situation by radically assuming it; through her flesh, her feelings and her behaviour, she will exalt as sovereign the one she loves, she will posit him as value and supreme reality: she will efface herself before him. Love becomes a religion for her.

In addition, other socio-economic factors, such as race, work status, age or class, may create power imbalances in a relationship. These power imbalances may lead to one partner's autonomy being subordinated. Moreover, the subordination of autonomy may not be rooted in any kind of power imbalance. Personality traits may also be an important influence. A timid and deferential person may end up playing a subordinate role in a relationship with an assertive and strong-willed person, even if the timid and deferential person possesses greater socio-economic power.

We must note that we do not think that mutual shaping, or even asymmetry in mutual shaping, is, by itself, negative. Mutual shaping can contribute to developing ourselves into the people we want to be. As Friedman notes, "Romantic mergers that nurture and affirm us can promote our autonomy as individuals by promoting our self-understanding, self-esteem, and capacities to act effectively in concert with others," (2003: 123-124). This enhancing of autonomy may even happen in imbalanced relationships. Think, for example, of an adventurer who meets her partner in a remote village. Although she lived in the village all her life, she always dreamt of seeing the world. In the relationship and new life with the adventurer, there may well be an obvious imbalance. But this could be a positive imbalance which does not constitute a subsuming relationship: the adventurer is helping her develop herself in a way that is expressive of her own autonomy. ${ }^{6}$

Having shown that the shaping of the lovers self-concept is a feature of love which has widespread support, and explained how this can be potentially dangerous if happening in a subsuming relationship, we now turn to discuss the process of falling out of love.

\section{Falling out of Love and Disorientation}

In the introduction, we showed that exiting a relationship can result in a disruption in selfconcept clarity. That possibility is at the centre of our claim, but we have chosen to focus on

\footnotetext{
${ }^{6}$ It would be interesting to investigate how imbalance may or may not result in a subsuming relationship, but unfortunately we cannot pursue that question without significantly deviating from our argument. In order to advance our claim on falling out of love, we only need to show that subsuming relationships exist.
} 
falling out of love, and not break-ups. The difference between falling out of love and breaking up is that the latter may be more directly under our control than the former. Also, some people fall out of love but never break up with their partners. Some other people choose to break-up with their partners without having fallen out of love. Finally, even in cases when the break-up is not chosen (like in cases when the other party decides to end the relationship), the left party usually ends up falling out of love with the former partner. We want to discuss what may happen in these cases in virtue of falling out of love, regardless of whether that results in (or from) a break-up.

We have seen that loving someone entails the acquisition of new interests and beliefs about oneself through mutual shaping, some of which become part of the lover's self-concept. This means that when one is in a relationship, the beloved is a point of reference in self-understanding, given that she contributes to shaping one's self-concept. When a person falls out of love, she may conserve the features of the self-concept she has acquired in the relationship like interest for the opera or the ballet. However, falling out of love means that she loses the receptiveness to be shaped by the former beloved. The beloved's interests which are not already her interests too do not interest her, and the beloved's interpretation of what she does just do not matter to her anymore. We are not arguing that this is what falling in love is, since we did not portray mutual shaping as what love is. Mutual shaping is a feature of love that is lost when one falls out of love. ${ }^{7}$ The person who falls out of love loses a 'co-shaper' of her own self-concept - that is what we mean by a point of reference in self-understanding.

We also argued that mutual shaping could lead to a subsuming relationship when one party in the relationship subordinates her autonomy to the other, who gains excessive control in the shaping of her self-concept. This by itself gives us sufficient resources to make one simple claim about the potential value of falling out of love. When someone in a subsuming relationship falls out of love, this can allow them to regain their subordinated autonomy. The reason for this is that it was their love for the other that led them to be excessively shaped by the other's interests and interpretations. Ceasing to love the other will involve ceasing to be receptive to mutual shaping, and so ceasing to subordinate their autonomy in respect to their self-concept in that way.

If the person in the subsumed relationship had been prioritizing the interests of the other, then falling out of love with that person will present them with an opportunity to act on their own values, rather than acting disproportionately on those of the person they love. If the person in the subsumed relationship has replaced her own interests with those of her beloved, then falling out of love will present her with an opportunity to become again the source of her own values. In either case, there is good reason to think that the extent to which the person has autonomy over her self-concept and the values that are expressive of her conception of a life worth living is increased.

This though, tells us only about the potential value of having ceased to love someone, i.e. of having fallen out of love. It does not support the claim that we wish to defend that the process of falling out of love can be valuable. For example, after being broken up with, or at the ending phase of a relationship, people may find themselves being less and less receptive to mutual shaping; less interested in the interests of the other. We argue that even in these cases, where

\footnotetext{
${ }^{7}$ It can be disputed that falling out of love eradicates any influence whatsoever from the beloved. After all, our self-concepts can also be shaped by people that we do not love, like therapists. Cocking and Kennett (1998: 523) acknowledge this, and argue that the therapist relationship has an end (improving the patient's mental health) which, once obtained, warrants the end of such relationships. Love does not have a specific aim, and that makes mutual shaping in love different in kind.
} 
falling out of love can be accompanied by emotional pain, the process itself can have value for the person undergoing it. The value of falling out of love hinges on the potential value of disorientation.

The starting point for our claim that the process of falling out of love can be valuable is that the process of falling out of love is typically one that involves disorientation. We follow Ami Harbin (2016: 2) in understanding disorientations as, "temporally extended major life experiences that make it difficult for individuals to know how to go on." In her Disorientation and Moral Life (11), Harbin points out that much moral philosophy assumes that disorientating experiences have only a negative role to play in moral life. Through in-depth examinations of experiences such as grief, trauma, migration, illness, queerness and double consciousness, Harbin examines the ways in which disorientations can be valuable. One kind of disorientating experience that Harbin mentions are romantic break-ups. Harbin (2016: xii) acknowledges in the preface to her book that coping with the break-up of a relationship may lead someone to become disorientated. In an earlier paper, Harbin (2014) develops an example of disorientation before and after a break-up in her discussion of author Charlotte Perkin Gilman's struggle during her marriage and after her divorce. The discussion on Gilman's self-doubt is rich, nuanced and enlightening on the disorientation attached to deciding whether to break up with someone, especially for people subject to social pressures to stay married (which is Gilman's case, a middle class white American in the nineteenth century). But our argument here is different: here we want to focus on the issue of falling out of love, which as we say above can happen before a break-up, after a break-up or within a continuing relationship.

To describe the disorientating potential of falling out of love, let us go back to Rebecca Bloom, the character we presented in the introduction. When Rebecca says "I don't know who I am without them" and asks "Who am I supposed to be now?" she is in an analogous situation to Harbin's disorientated person. She does not know how to go on. But note that she is not merely asking "what should I do next?". She is disorientated about who she is. Rebecca is an extreme case where the loss of a point of self-understanding entailed by falling out of love results in a total loss of self-concept clarity: she does not even know what to think about herself. She thus needs to engage in self-reflection and evaluation in order to find clarity, which may mean returning to her former self-concept, or selecting the parts of her self-concept that she acquired in the relationship that express her autonomy, or even developing a new selfconcept altogether. It can even be the case that after an initial loss of self-concept clarity, Rebecca's beliefs about herself remain the same as they were in the relationship. But she will nevertheless have to re-formulate that self-concept. Next, we explain why this can be valuable.

\section{The Value of Falling out of Love}

Having outlined the form of disorientation that may accompany the process of falling out of love we will now argue that this experience can have both prudential and moral value. This disorientation could be valuable in alerting someone to the extent to which their own autonomy was subordinated in their previous relationship. The experience of being wrenched from a relationship that played a major role in defining their self-concept could lead to a realisation of how much the relationship consumed their autonomy and alienated them from their own conception of a life worth living. This in turn could lead someone to consider the process by which they allowed their autonomy to be subordinated in a subsuming relationship. 
This could play a valuable role in prompting someone to consider the extent to which they are willing to allow their autonomy to be subordinated like this in the future.

Novelist Kate Christensen is a good example of the disorientating experience of falling out of love playing this role. Hers is a case of falling out of love after a break-up, but our interest is in what is happening to her in the process of falling out of love, which could have happened while being in the relationship. In a letter to her ex-husband, Christensen wrote to her ex-lover to, in her words, "clarify things for myself," (Christensen 2002: 60). In her letter, Christensen writes about the disorientation she experiences. She describes how she is unable to, "explain what I mean or why I am the way I am or who I am, even," (Christensen 2002: 60). This disorientation leads Christensen to rethink her love affair, she describes how she, "lay awake for hours, and I thought about why I'm leaving, because I don't think I've ever fully articulated it to either of us," (Christensen 2002: 60). In this process she recalls the way she responded to signs of incompatibility at the beginning of their relationships: "I tried to adapt myself and change and be who you wanted instead of moving on. .. I sort of gave myself willful amnesia, hoping things would just "work out", (Christensen 2002: 61). She observes the way in which the relationship has changed her in a negative way, saying:

I was like a completely different person: confident, intelligent, ambitious, loving, kind and easygoing. I demanded to be listened to with the same respect I afforded others. I didn't take this kind of shit from anyone. Now I feel like I am in a cult of two [...] like I've been worn down and made to behave in ways that are anathema to who I really am. (Christensen 2002: 62).

Realising the extent to which she has given up her autonomy she concludes that she has to go back to being someone she can endorse: someone whose life is worth living according to her own terms. In her words: "I have to go away. I have to go back to self-integrity and self-love and what I truly believe in, to lightness, warmth, taking responsibility for yourself," (Christensen 2002: 62). In addition, Christensen resolves never again to be involved in a love affair that will require her to abandon her values, saying: "I want to be with someone who loves me because I'm light and not in spite of it, someone who doesn't try to turn me into someone else," (Christensen 2002: 63 Emphasis Added).

Christensen's case is a clear example of the disorientating process of falling out of love leading someone to think about the way in which they have subordinated their autonomy in their love for another person and recognizing the need not to do so again in future. Because it causes this self-examination, the disorientation here is prudentially valuable, by which we mean it promotes the well-being of the person who experiences the disorientation. This selfexamination raises Christensen's awareness of the ways in which she responded to her beloved led her to abandon her autonomy and acquire a self-concept which does not adjust to her conception of a life worth living. This in turn leads to the realization that she must look for a lover who will not require her to subordinate her autonomy in this way.

This realization may be prudentially valuable, in two ways. First, it is likely to be of instrumental prudential value. If she is able to act in line with it then she should be less likely to enter into relationships that harm her well-being by requiring her to subordinate her autonomy to that of her beloved (though of course she may still end up in such relationships or in relationships that have a negative impact on her well-being in other ways). Second, on some views of well-being, this realization may also be non-instrumentally valuable. An objective list theory of well-being may hold knowledge to be non-instrumentally valuable 
(Eg. Parfit 1984: 499). If we think of this realization as a form of knowledge then according to this view of well-being, the realization will be of non-instrumental prudential value.

So far we have outlined the ways in which the disorientating process could be valuable for the person who has fallen out of love. But in addition to this prudential value, this process could also be morally valuable. The experience of disorientation could highlight the norms that encourage women and other disadvantaged groups to allow their autonomy to be subordinated in romantic relationships. Harbin discusses the power of disorientations to raise our awareness of oppressive norms in relation to double consciousness and white ambush (2016: 68-77). Similarly, a woman undergoing the disorientating experience of losing the point of reference in self-understanding may raise her awareness of the norms that pushed her to subordinate her autonomy in the first place. She may become more aware of the ways in which others responded to her when she was in the relationship as someone subordinated to the other. This heightened awareness may make people more aware of how to respond to these norms in the future. This could of course be prudentially valuable in enabling people to better navigate their way around these norms. It could also be of moral value, as it may lead the person who has fallen out of love to an increased awareness of the ways in which she has acted to support and uphold these norms towards others. This awareness combined with the knowledge of the ways in which subordinating one's autonomy in one's love for another can be harmful, may well lead to an attempt to make sure one does not act to uphold these norms in the future. However, as Harbin (2016: 89) points out, gaining increased awareness of oppressive norms can be valuable even if it does not lead to increased resolve about how to act. Simply being aware of the oppressive nature of these norms and the harms that can result from them can be morally valuable, even if it does not result in a clear view of how we should act in the future.

It might be objected that this account of the value of falling out of love would only apply to people in subsuming relationships. The value we have identified arises from the insight into the way in which someone responded to their beloved by subordinating their autonomy, as well as the social norms that supported and encouraged this. This would only provide insight for those who have subordinated their autonomy in this way. So our account has nothing to say about the value of love for those in more equal relationships. This objection does not cast doubt on our argument but it does show the limits of its scope.

However, the arguments we have made about the value of falling out of love can be extended to cover more equal relationships. The process of falling out of love with someone would also be disorientating for those in equal relationships, as their self-concept would also have been co-shaped by their former beloved. They too will likely experience a sense of disorientation after losing this point of reference in self-understanding and their understanding of the world. This disorientation is likely to lead them to consider the ways in which their selfconcept was changed by their love for the other. In the case of a positive relationship though this could lead to a consideration of the ways in which their self-concept has changed in ways they endorse and the ways in which their love enabled these changes.

It is also worth noting that a positive loving relationship may exist between two people with no long-term compatibility. The fact that two people are not compatible with each other does not mean that they cannot support each other and promote each other's interests. Suppose Jaap and Kurt have been in a supportive loving relationship in which neither's autonomy is subordinated to the other. However, Jaap wants to spend all his time partying, travelling and exploring the world and Kurt wants to build a home and a family with someone he loves. Jaap and Kurt may realise over time that they are not a good fit for each other and eventually, because of this or not, fall out of love -i.e. stop 
being receptive to be mutually shaped by each other. The disorientation each may experience while falling out of love with the other may lead them to consider the ways in which their self-concept was changed by the other, as well as they ways in which they were unable or unwilling to change. This may lead to a developed self-understanding of the way in which the other facilitated these changes in their self-concept. It may also bring a heightened awareness to the aspects of their self-concept that truly express their conception of a life worth living, and the kinds of changes that they would not be willing to make for a lover. This self-understanding is likely to be prudentially valuable, both in for its own sake and because it improve Jaap and Kurt's chances of finding fulfilling future relationships. It may also be of moral value of a quite different kind to that of the disorientation involved in falling out of love with someone with whom one was in a subsuming relationship with. Understanding the way in which the other facilitated changes that they approve of may lead Jaap and Kurt to develop a sense of gratitude towards each other. This is morally valuable in and of itself but is also likely to help them act respectfully to each other after the break up. While these positive effects of the disorientation of falling out of love may not be as significant as those for someone who has subordinated their autonomy to their beloved, they remain important and worth recognizing.

\section{Practical Implications}

We have argued that the disorientating experience of falling out of love with someone can be both prudentially and morally valuable. We will finish by arguing that accepting this claim has important implications for how we should respond to those going through the disorientation of falling out of love.

In the final chapter of Harbin's (2016: Ch. 6) book about disorientation, she argues that how we respond to disorientated people can affect how that disorientation is experienced. Key to making sense of this claim is the idea that the emotions people experience and the way in which they are experienced are influenced by the emotions they are enabled to express (Scheman 1980; Spelman 1989). It is easier for some people to express certain emotions than it is for others to do so. Men for example may be more enabled in their expression of anger than women (Spelman 1989), though we should also be aware of the influence that other sources of oppression, such as race, may have on who is enabled to express anger. The fact that it is harder for women to express their anger is important, as it can result in women being less likely to be angry. This point is not simply the epistemic claim that it would be more difficult for women to know they are angry. It is the stronger, ontological claim that how people are supported in the expression of certain emotions may influence what emotions actually exist (Harbin 2016: 157). That is not to say that is impossible for someone to be angry if they are not supported in the expression of anger. Rather it is the weaker claim that not being enabled to express anger may influence someone's ability actually to be angry. Karen Jones (2008) makes this same point about being in love. People who live in "societies structured by compulsory heterosexuality" may not even be able to conceptualise certain attitudes towards people of the same sex as being in love, given that they lack the conceptual framework (Jones 2008: 281). Again, it would not be impossible for these people to be in love with people of the same sex, but it may influence their ability to be in love with people of the same sex - for example, they may conceptualise closeness and affection as friendship, not romantic love.

Harbin (2016: 157) claims that the same goes for disorientations. The way in which people respond to potentially disorientated others will affect the extent to which they are enabled to 
express their experience of disorientation. For example, someone raised in a religious community returns home after a first semester at college with doubts about his religious commitments. His family may allow no room for the student to express his doubts and feelings of disorientation. This may prevent the student from experiencing disorientation and instead write-off his doubts as an adolescent crisis. Again the point is not simply that making it difficult for people to express disorientation will make it harder for people to know that they are disorientated. Rather it is the stronger claim that lacking the environment that would enable one to express disorientation can prevent people from actually being disorientated. One way in which people may make it hard for others to express disorientation is by pushing them to reorient themselves. People may be told to 'pull themselves together', to 'get a grip' or to 'sort themselves out'. This push for reorientation is damaging, according to Harbin (2016: 157158), as it can make it harder for people to benefit from the potential that disorientations have to play a positive role in our lives.

This point has important implications for how people should respond to the disorienting experience of falling out of love. What Kate Christensen is doing in the process we describe above is precisely navigating her disorientation, not so much by trying to obliterate it but by trying to make sense of what happens next. Trying to re-orientate herself too fast would deprive her of the value she can obtain from the disorientating process. This is particularly important if we consider the common advice given to people who are falling out of love: "There's plenty more fish in the sea"; "One devil drives out another". In other words: "Reorientate yourself quickly by starting a new process of mutual shaping!". That is what is commonly understood as a 're-bound', ie. jumping from one relationship to another without engaging in any self-reflection.

We do not intend to claim that there is an appropriate amount of time to re-engage in romantic relationships after falling out of love or experiencing an unchosen break-up. However, from this example we can extract a responsibility that we have towards ourselves and others. The re-bound advice comes from the tendency to speedy re-orientation that Harbin warns against, translated to the romantic realm. But we have seen that the disorientations that result from falling out of love can be helpful if they lead to self-reflection. What is more, in the case of vulnerable groups, the pursuit of quick re-orientation may perpetuate the subordination of their autonomy. So we have a duty to at least refrain from advising fast re-orientation to others, due to the risk that this will create personal and social harm. By telling someone that getting a new partner is the solution to their emotional pain, we are potentially contributing both to their future unhappiness and to the perpetuation of inequality.

As to the responsibility to ourselves, we do not want to go as far as to claim that we have a duty not to engage in re-bounds or serial monogamy. But at least we should recognize the value of the process by looking back at the relationship we just left, at how much we gave up and how much that changed our identity. And in sum, to at least pose the question to ourselves of "How do I go on?" in case we can learn something from it.

\section{Conclusion}

In this paper, we have looked into an important and under-investigated source of disorientating experience, that of falling out of romantic love with someone. We began by showing the consensus on love entailing a change in the beloved, in virtue of the acquisition of mutual interests. This change is a result of the process of mutual shaping, which leads the lovers to act 
in virtue of the other's interests and their respective interpretation of each other - which eventually shapes the lovers' respective self-concept. This process of mutual shaping has certain dangers, given that a person can give up too much autonomy in determining her values, i.e. the expressions of the life she considers worth living. This is a danger for anyone entering into a love affair but the existence of oppressive gender norms linked to romantic partnerships means that it is a danger that is particularly likely to befall women in their romantic relationships with men. However, because love involves mutual shaping, falling out of love involves a disorientating change in our self-concept. This often prompts a re-evaluation of who we were in the relationship and who we are now. This re-evaluation can be of moral and prudential value. For those who have been in subsuming relationships it is likely to bring insight into the way in which someone responded to their beloved by subordinating their autonomy, as well as the social norms that supported and encouraged this. In cases of more equal relationships, the recognition of the way in which lovers have shaped each other's selfconcept may facilitate a deeper self-understanding of the ways in which each is and is not willing to allow themselves to be changed by their lovers. It may also foster a sense of gratitude for the ways in which the other has helped to facilitate changes in their self-concept that they approve of. The value arising from this disorientation gives us reason to be wary of seeking to re-orient ourselves or others too quickly after falling out of love. ${ }^{8}$

Open Access This article is licensed under a Creative Commons Attribution 4.0 International License, which permits use, sharing, adaptation, distribution and reproduction in any medium or format, as long as you give appropriate credit to the original author(s) and the source, provide a link to the Creative Commons licence, and indicate if changes were made. The images or other third party material in this article are included in the article's Creative Commons licence, unless indicated otherwise in a credit line to the material. If material is not included in the article's Creative Commons licence and your intended use is not permitted by statutory regulation or exceeds the permitted use, you will need to obtain permission directly from the copyright holder. To view a copy of this licence, visit http://creativecommons.org/licenses/by/4.0/.

\section{References}

Abramson K, Leite A (2011) Love as a reactive emotion. Philos Q 61(245):673-699

Baumeister RF (2005) Self-concept, self-esteem, and identity. In: Derlega VJ, Winstead BA, Jones WH (eds) Personality: contemporary theory and research, 3rd edn. Thomson/ Wadsworth, Belmont

Bowen S (2002) Stella Bowen to ford Maddox ford. In: Holmes A (ed) Hell hath no fury: Women's letters from the end of the affair. Random House, New York

Campbell J et al (1996) Self-concept clarity: measurement, personality correlates, and cultural boundaries. J Pers Soc Psychol 70(1):141-156

Christensen K (2002) Kate Christensen to John. In: Holmes A (ed) Hell hath no fury: Women's letters from the end of the affair. Random House, New York

Cocking D, Kennett J (1998) Friendship and the self. Ethics 108(3):502-527

De Beauvoir S (1949 [2011]) The Second Sex trans. C. Borde and S. Malovany-Chevallier. Vintage Books, London

Frankfurt H (2004) The reasons of love. Princeton University Press, Princeton

Friedman. M. (1998). Romantic Love and Personal Autonomy. Midwest Studies in Philosophy 22 (1):162-181. Friedman M (2003) Autonomy, gender, politics. Oxford University Press, Oxford

Harbin A (2014) Disorientation and the medicalization of struggle. Int J Fem Approaches Bioeth 7(1):99-121

\footnotetext{
${ }^{8}$ Thanks to Huub Brouwer, Amanda Cawston, Martha Claeys, Dieter Declercq, Henk van Gils, Ami Harbin, Kristien Hens, Tim Klaassen, James Lewis, Hans Maes, Constantin Mehmel, Christoph Menke, Lubomira Radoilska, Katrien Schaubroeck, Maureen Sie, Lotte Spreeuwenberg, Clint Verdonschot, Nathan Wildman and two anonymous referees for helpful feedback on earlier versions of this paper.
} 
Harbin A (2016) Disorientation and moral life. Oxford University Press, Oxford

Helm B (2010) Love, friendship, and the self. Oxford University Press, Oxford

Jones K (2008) How to change the past. In: Mackenzie C, Atkins K (eds) Practical identity and narrative agency. Routledge, Oxford

Keller S (2000) How do I love thee? Let me count the properties. Am Philos Q 37(2):163-173

Kolodny N (2003) Love as valuing a relationship. Philos Rev 112:135-189

Korsgaard C (1996) The sources of normativity. Cambridge University Press, Cambridge

Krebs A (2014) Between I and thou - on the dialogical nature of love. In: Maurer C, Milligan T, Pacovská K (eds) Love and its objects. What we can care for? Palgrave Macmillan, London

Mackenzie C, Poltera J (2010) Narrative integration, fragmented selves, and autonomy. Hypatia 25(1):31-54

Naar H (2013) A dispositional theory of love. Pac Philos Q 94(3):342-357

Nozick R (1989) The examined life: philosophical meditations. Simon \& Schuster Paperbacks, New York

Oshana M (2006) Personal autonomy in society. Ashgate Publishing, Aldershot

Parfit D (1984) Reasons and persons. Oxford University Press, Oxford

Scheman N (1980) Anger and the politics of naming. In: McConnell-Ginet S, Borker R, Furmen N (eds) Women and language in literature and society. Praeger Publishers, New York, pp 174-187

Slotter E, Gardner WL, Finkel EJ (2010) Who am I without you? The influence of romantic breakup on the selfconcept. Personal Soc Psychol Bull 36(2):147-160

Soble A (1990) The structure of love. Yale University Press, New Haven

Spelman EV (1989) Anger and insubordination. In: Garry A, Pearsall M (eds) Women, knowledge, and reality: explorations in feminist philosophy. Unwin Hyman, Boston, pp 263-273

Walker MJ (2012) Neuroscience, self-understanding, and narrative truth. Am J Bioeth Neurosci 3(4):63-74

Publisher's Note Springer Nature remains neutral with regard to jurisdictional claims in published maps and institutional affiliations. 